\title{
Promoting health and well-being of entrepreneurs with health technology
}

\author{
Reetta Raitoharju', Katja Heikkinen ${ }^{1}$ \\ ${ }^{1}$ Turku University of Applied Sciences, Finland
}

\begin{abstract}
In Finland the number of entrepreuneurs over 55 years old has increased from 60.000 to 100.00 between 2000-2010. The growth has continued since that and now, there are 113.000 entrepreneurs in Finland who have reached the age of 55. Most of the companies in Finland are micro or SSM's and the responsibility of entrepreneurs' health and well-being is lies often on the shoulders of the entrepreneurs themselves. Supporting this group by giving them means more effectively to take action in preventing work-and age-related injuries and problems can help in prolonging careers.

Entrefox is a project funded by European Social Fund and it aims at promoting the health and well-being of entrepreneurs and future entrepreneurs over the age of 55 especially following the principles of active ageing and lifelong learning. Three groups of 10 entrepreneurs will be organized to create their own well-being plans and to give them means to follow the progress of their plan. Health technology will be used to help observing and motivating the process. Furthermore, students from different fields (physiotherapy, engineering and health promoting) will be included to support the entrepreneurs.
\end{abstract}

Keywords: entrepreneurs, health promotion, health technology 


\section{Introduction}

Finnish economy is facing challenges caused by the ageing population and therefore, prolonging working careers and including all the citizens into the workforce is crucial. Entrefox is a project funded by European Union Social Fund that supports +55 year entrepreneurs in active ageing and life long learning. Entrepreneurs often retire older than people working on salary in average. Moreover, +55 year workforce often have a lot of knowhow, tacit knowledge and networks that are very valuable for the economy.

For most of the entrepreneurs, entrepreneurship is an intended and valued way of making a living. The amount of entrepreneurs that have ended up of being entrepreneurs only because of the circumstances is lower in Finland than in EU countries in general. However, the job satisfaction among the Finish entrepreneurs is lower than in EU in general. Especially grand this difference is between the Finnish and other Scandinavian entrepreneurs. (Tilastokeskus 2018.)

There are several definitions on well-being. With the well-being of the entrepreneurs we mean the experience of satisfaction of people's life. Actually, well-being should be considered an umbrella term that reflects multiple dimensions instead of capturing something unidimensional. (Wiklun et al. 2019.)

Almost one in five (18\%) entrepreneurs often reported having difficulties working in 2017. A quarter $(24 \%)$ of the entrepreneurs felt of neglect in the work - especially with the specialist experts in knowledge work. (Tilastokeskus 2018.)

One of the current megatrends of health care is that the treatment is transformed from massoriented care towards individual care. Technology offers us new ways to promote individual and self-care. Self-care services are a way to increase the well-being of Finns and to target healthcare more effectively. Finland already has electronic services for promoting well-being and monitoring health. A high percentage of Finns say that they like monitoring their own health and looking after themselves. (Sitra)

Technology can be used in several ways to support health and well-being activities. For instance different activity trackers and health apps is becoming increasingly popular. In many cases, older adults are the fastest growing computer and Internet user group in both personal and workplace contexts. (Wagner 2010) Overall, technology is an important tool in improving access to health care for older people and empowering them to take an active role in health activities. (Czaja 2013)

\section{Entrefox project}

Entrefox will be implemented between 1.2.2019 - 31.12.2021 by Turku University of Applied Sciences, Finnish Institute of Occupational Health and University of Helsinki. The 
Finnish ESF project is linked to Sweden's corresponding ESF project, "BSLF Sustainable Working Life - SWL", where the key themes are lifelong learning and active aging. Other international partner countries are Latvia and Lithuania.

In Entrefox, there are four different workshops that are aiming at supporting active ageing and life long learning of +55 year entrepreneurs. These workshops cover multiple issues such as digital capabilities or peer-support. In this paper we concentrate on descriping one of the workshops that is particulary aiming at increasing the physical well-being and heatlh at work.

In order for +55 year entrepreneurs to be able to work longer and cope with the demands of the changing working life, attention should be paid to foster their health and well-being. In scope should not only be those risks caused by work itself but also the changes brought by the age should be considered and prevented. Especially in small companies the entrepreneurs often are themselves responsible of their working conditions and well-being and support and tools to enhance that is the goal of the health and well-being workshops in Entrefox.

In health and well-being workshop, a tool will be created that helps +55 year entrepreneurs to take active role in developing their own well-being and coping with work. The tool is based on entrepreneurs' own goals and monitoring the progress. Special emphasis is paid on using health technology.

The project is carried out three workshops for the participants during the half-year. In the the first workshop we will focus on defining the participants' own well-being goals. Thereafter, the participants will have the opportunity to participate in the physical fitness assessment and physical body measurement performed by the physiotherapist students and professionals (Liilab). Participants will have the opportunity to communicate with each other and with project staff through Skype.

Master students from health and-wellbeing will plan and organize the workshops.

\section{Evaluation of the project}

For all the Entrefox project participators, there is a questionnaire form covering issues such as perceptions about own capabilities, perceptions about the future, and engagement to work. This questionnaire will be handed out both at the beginning of the workshops as well as at the end. The questionnaire is aimed at capturing possible change in satisfaction, capabilities and well-being during the Entrefox participation.

Besides that, participants will get questionnaire about their wishes and expectations in advance. During the workshops, participants are also asked to evaluate the usefulness of the workshops and the progress of well-being. These results are used to co-create better 
workshops and tools for the +55 entrepreneurs. Results are also analysed to create the endevaluation of the project.

\section{Conclusions and future research}

As an end-product of Entrefox, we wish to build a tool that can be used by the +55 year old entrepreneurs when developing their job satisfaction and well-being. However, this tool will only be based on the Finnish data and experiences and it would be most valuable to expand this work also internationally. Therefore, we are interested in expanding the project internationally in the future and are in search for partners to join us.

\section{References}

Czaja, S, Beach, S, Charness, N, Schulz, R, 2013, Older Adults and the Adoption of Healthcare Technology: Opportunities and Challenges, In Technologies for Active Ageing eds. Sixsmith, A and Gutman, G. Springer 2013.

LiiLab 2019. http://www.turkuamk.fi/fi/tyoelamapalvelut/palvelut/liikunta-jatoimintakykylaboratorio-liilab/

Sitra. https://www.sitra.fi/en/topics/self-care/\#latest

Tilastokeskus 2018. YRITTÄJÄT SUOMESSA 2018. Sutela H \& Pärnänen A. Helsinki 2018.

http://www.stat.fi/tup/julkaisut/tiedostot/julkaisuluettelo/ytym_201700_2018_21465_ne t.pdf

Wagner, N, Hassainen, K, Head, M, 2010, Computer use by older adults: A multi-disciplinary review, Computers in Human Behavior 26(5), P 870-882

Wiklund, J, Nikolaev, B, Shir, N, Food, M-D Bradleye, S. 2019.

Entrepreneurship and well-being: Past, present, and future. Journal of Business Venturing 34(4), 579-588. https://doi.org/10.1016/j.jbusvent.2019.01.002 